\title{
Simpson Grade 5
}

National Cancer Institute

\section{Source}

National Cancer Institute. Simpson Grade 5. NCI Thesaurus. Code C128621.

Simple decompression, with or without biopsy. 